\title{
Evaluation of Full Day School Program at SD Negeri Takkalasi
}

\author{
Kamaruddin Hasan ${ }^{1}$, Rasmi Djabba ${ }^{2}$, Rita Tuken ${ }^{3}$ \\ \{kamaruddinhasan.1973@gmail.com ${ }^{1}$,djabba.rasmi@gmail.com ${ }^{2}$, ritha.tuken@unm.ac.id ${ }^{3}$ \} \\ ${ }^{1.2,3}$ Elementary Department, Universitas Negeri Makassar, Makassar, Indonesia
}

\begin{abstract}
This study aimed to evaluate (i) Full Day School program plan at SD Negeri 1 Takkalasi, (ii) implementation of Full Day School program at SD Negeri Takkalasi, and (iii) product of Full Day School program at SD Negeri Takkalasi. This study was evaluation research with qualitative approach. This evaluation utilized Stake model evaluation program which consisted of input, process, and product. The subjects of this study were headmaster, deputy head, teachers, and students' parents. Data were collected by observation, interview, and documentation. Data were analyzed by data collection, data condensation, data display, and conclusion. Evaluation result showed (i) program plan which was consisted of curriculum, facilities, and infrastructure was good, but it had lack of fund and human resources, (ii) implementation of program in religious, arts, sports, scout, and knowledge and skills field was good, but there were students' parents who did not support the program and teachers had difficulty in controlling some students, and (iii) program products were good where students attended sholatul jama'ah and improved their talents, and there were 55 students who had memorized Juz 'Amma. Thus, Full Day School program at SD Negeri Takkalasi can be continued with an additional number of innovative teachers, socialization to students' parents about positive impacts of this program, and additional funds.
\end{abstract}

Keywords: Full Day School, Evaluation, Stake Model

\section{Introduction}

Full Day School program can maximize character education in formal education. Full Day School program is school program where learning process is implemented full day at school, so that students spend more time at school than outside the school which causes worried especially for the parents. Students can be at home soon after the learning process at school. Full Day School Program applies longer learning process because it applies more intense and more comprehensive course than regular program. Thus, learning process covers all the students' activity at class or outside the class.

Full Day School program aims to develop students' character for being goodhearted human for God and others people. Full Day School Program is expected can increase students' ability on science and technology and also increase students' belief and devotion to God, so that students have affective, cognitive, and psychomotor competence. Full Day School 
Program is not only develops students' creativity on academic domain, but also on non academic domain.

Full Day School program which has good purpose is still cause pro and contra in society. There are people who assume the program bothers the students. There are found difficulty at students. Students feel boring and want to go back home as soon as possible, so that it decrease students' concentration in following the learning. Time increasing on learning process also affects in increasing teachers activity, so that it can decrease teachers' performance.

Children in elementary age spend more time on playing than learning. Because of that, need concept assimilating of Full Day School program, so the program does not remove children's playtime. Teachers should utilize attractive learning strategy and grab children's attention.

Full day school program is general school model with intensive religious learning system by increasing time on religious matter and extracurricular for students. For applying the program, Full Day School program is equipped enjoyable learning for students, so students will not be boring at school. Besides that, teachers should be role model in social, emotional, and spiritual behavior for students because students spend much time at school.

Full Day School program at elementary school is designed to provide more experience for students such as picnic, visiting park, visiting zoo, and so on. Besides that, students also can identify various professions from invited guest at school. The purpose of Full Day School program is making students busy at school in learning by producing effective learning time so that they will not play all day long outside their home when they go back from the school. The advantages of Full Day School program are students obtain various learning method which different with students on regular school program, have more playtime and studying time with friends, the parents will not worry about their children because their children full day at school and spend more time for studying, and the parents will not afraid of their children will be affected by negative effect because their children in school control.

Definition of program evaluation based on Cronbach (1963) and Stufflebeam (1971) in Arikunto (2014:5) is effort to provide information to decision maker. According to Arikunto (2014), program evaluation is one kind of research, namely evaluation research. Because of that, in program evaluation, researcher thinks and determines steps as like other research.

In addition, Wirawan (2011:17) defined program evaluation is systematic method to collect, analyze, and utilize information to answer fundamental question about the program. Wilbur Harris in Sudjana (2006:19) stated program evaluation is systematic decision process about value, purpose, effectiveness or compatibility of something to criteria and purpose that has been decided before. Decision process is based on proportion of observation data carefully by using certain standard that has been standardized. This program evaluation limit contains three important substances, such as systematic activity, data, and decision making.

Thus, we can conclude that program evaluation is systematic activity to collect, process, analyze, and present information with systematic method then assess the program by comparing it with standard (criteria) and the result is utilized to take decision about the evaluated program.

In addition, Stake in Arikunto (2014:44) said when evaluators are considering education program, they should utilize two proportion, such as compare the result condition of certain program evaluation with other program, with same target object and compare the result condition of certain program evaluation with the program standard, based on achievement purpose. 
According to Tayibnapis (2008:21), evaluation process analysis by Stake carried large impact in evaluation domain and put simple fundamental but the concept was strong enough for development of evaluation domain. Stake (in Arikunto, 2014:43) emphasized two fundamental activities such as (1) description and (2) judgements; and then distinguished three steps of program evaluation, such as (1) antecedent/context, (2) transaction/process, and output-outcomes.

Thus, antecedents, transaction, and outcomes of data which compared are not only to determine the different between the purpose and the real condition, but also compared with absolute standard to assess program advantages (Tayibnapis, 2008:22).

Research of Hidayati, Tohiroh, \& Istyarini (2017) is about program evaluation of character education at Sekolah Dasar Islam Terpadu full day school. Their research concluded if the program plan of character education on human resource, facility, and infrastructure were still needed to be improved, implementation of character education program has been integrated well with all of learning activity at school, and result of character education program on character of religious, honest, and politeness was suitable with the program purpose, but on characters of responsibility and environmental love were still needed to be improved. The conclusion is the plan program and the result program are needed to be improved.

Research of Rahayu, Abidin, \& Susilaningsih (2018) is about evaluation of Full Day School learning program at SDN Bunulrejo 2 Malang which concluded if the school can continue Full Day School learning program because the program can provide advantages in facilitating talent and interest of students and grant necessities of worker parents. According to evaluation result, there are several recommendations to make Full Day School learning program at SDN Bunulrejo 2 Malang can achieve the purpose, such as classroom is needed to be enhanced to support extracurricular activity in supporting program achievement, teachers are needed to give motivation to students so students have high awareness in compressing their academic achievement, and the program needs collaboration and support from students' parents to build better characters on students.

Research of Suranto \& Seftiana (2017) is about implementation of Full Day School policy for students' learning outcomes. This research concluded that implementation of Full Day School policy to improve students' learning outcomes at MAN 1 Surakarta on curriculum aspect was good. MAN 1 Surakarta utilizes curriculum of 2013 which developed to be laboratory based on where there is life skill activity which implemented integrally and the school collaborates with around environment in learning program and then involved the students in social interaction, such as visiting university, Primagama, Ganesha Operation, Smart Gama, and English organization. Supporting factors in implementation of Full Day School policy at MAN 1 Surakarta are getting enough of human resource and there is integration between school, students' parents, and environment. Obstacle factor in implementation of Full Day School policy at MAN 1 Surakarta is lack of facility and infrastructure such as classroom and social science laboratory. Role of implementation of Full Day School policy for students' learning outcomes is observed on improvement of students' learning outcomes at each semester test. Thus, implementation of Full Day School policy has important role in improving students' learning outcomes.

Research of Latief \& Hasanah (2017) is about evaluation of implementation of character education with full day school system at Madrasah Ibtidaiyah Negeri Al Azhar Asy Syarif Indonesia. This research concluded that implementation of Full Day School program at Madrasah Ibtidaiyah Negeri Al Azhar Asy Syarif Indonesia is suitable with government rules and the program makes better character education process. 
SD Negeri Takkalasi is the only one elementary school at Barru district which implements Full Day School program. Because of that, we need to evaluate the implementation of Full Day School program at SD Negeri Takkalasi. Evaluation of implementation of Full Day School program is carried out to know the achievement of the program. Program evaluation can give information about what the achievement of the program is and not yet achieved and then it can give recommendation to improve the implementation of the program.

Remember the important of this Full Day School program which recently applied on elementary school at Barru district, so that we are interested to do evaluation research with the title, evaluation of Full Day School program at SD Negeri 1 Takkalasi. This research aimed to evaluate (i) Full Day School program plan at SD Negeri 1 Takkalasi, (ii) implementation of Full Day School program at SD Negeri Takkalasi, and (iii) product of Full Day School program at SD Negeri Takkalasi.

This research is based on theory about program evaluation is one of procedure that researchers utilize to obtain the information about implementation of Full Day School program. On this research, the information which is needed is Full Day School program plan, implementation of Full Day School program, and product of Full Day School program at SD Negeri Takkalasi. Besides that is undertaken to know the achievement of the implementation of Full Day School program based on criteria. The information can be obtained from data processing to determine the implementation of Full Day School program at SD Negeri Takkalasi has been suitable with the criteria or not.

\section{Method}

This evaluation is program evaluation with Stake model. This evaluation model is developed by Robert E. Stake with descriptive qualitative approach that consisted of input, process, and outcome. Each step is divided in two steps, namely description and judgment. This evaluation was undertaken at SD Negeri Takkalasi. The research subject is Full Day School program. Sources of data are headmaster, deputy head, teachers, and students' parents. Data were collected by observation, interview, and documentation. Thus, three evaluation components of Full Day School program at SD Negeri Takkalasi can be described on this Table 1. below.

Table 1. Evaluation Components

\begin{tabular}{|c|c|c|c|}
\hline $\begin{array}{l}\text { Evaluation } \\
\text { Components }\end{array}$ & Aspect & Source of Data & Data Collecting Technique \\
\hline Input & $\begin{array}{ll}- & \text { Curriculum } \\
\text { - } & \text { Human Resource } \\
\text { - } & \text { Facility and } \\
& \text { Infrastructure }\end{array}$ & $\begin{array}{ll}\text { - } & \text { Headmaster } \\
\text { - } & \text { Deputy head } \\
\text { - } & \text { Teachers } \\
\text { - } & \text { Students' } \\
& \text { parents }\end{array}$ & $\begin{array}{ll}\text { - } & \text { Interview } \\
\text { - } & \text { Observation } \\
\text { - } & \text { Documentation }\end{array}$ \\
\hline Process & $\begin{array}{ll}\text { - } & \text { Learning plan } \\
\text { - } & \text { Learning } \\
& \text { implementation } \\
\text { - } & \text { Learning outcomes } \\
& \text { assessment } \\
\end{array}$ & $\begin{array}{ll}\text { - } & \text { Headmaster } \\
\text { - } & \text { Deputy head } \\
\text { - } & \text { Teachers } \\
\text { - } & \text { Students' } \\
& \text { parents } \\
\end{array}$ & $\begin{array}{ll}\text { - } & \text { Interview } \\
\text { - } & \text { Observation } \\
\text { - } & \text { Documentation }\end{array}$ \\
\hline Outcome & $\begin{array}{l}\text { - } \text { Students' } \\
\text { achievement on } \\
\text { affective, cognitive, }\end{array}$ & $\begin{array}{ll}- & \text { Headmaster } \\
\text { - } & \text { Deputy head } \\
\text { - } & \text { Teachers } \\
\end{array}$ & $\begin{array}{ll}\text { - } & \text { Interview } \\
\text { - } & \text { Observation } \\
\text { - } & \text { Documentation }\end{array}$ \\
\hline
\end{tabular}


Data analysis technique which is undertaken in this research is qualitative descriptive technique that consists of data collection, data condensation, data display, and conclusion. Data analysis process is started with data collection and then examining the collection data. On data collection, researchers note all of the information objectively as the real condition of source of data from interview, observation, and documentation result. After careful reading, studying, and examining, so the next step is data condensation. The researchers select, concentrate the attention on simplification, abstract, and transform the data from the field. After that, the researchers implement the categorization by using certain categorization criteria. Data display is directed to make condensation result data is organized, so that data is easy to be understood. Data display in narrative description. Next step is data validity checking and conclusion.

\section{Result and Discussion}

research result and discussion consist of three components, namely (1) input evaluation of Full Day School program, (2) process evaluation of Full Day School program, and (3) outcome evaluation of Full Day School program. The description of each component is as follow as.

\subsection{Input Evaluation of Full Day School Program}

Input program achievement indicators are curriculum, human resource, and facility and infrastructure that can organize all of Full Day School program activity at SD Negeri Takkalasi. According to research result, input of Full Day School program at SD Negeri Takkalasi is good.

The first is curriculum aspect where there are mandatory lesson subject and extracurricular in religiousness, arts, sport, scout, and knowledge and skill. Thus, students do not only learn at class, but also there are talent and interest intensive to improve students' competence. School has prepared schedule for all of the activity on Full Day School program at SD Negeri Takkalasi.

How a curriculum is planned poses itself as one of the most important factors that predetermines the success and effect of curricular implementation. Curriculum planning and instruction are closely connected to each other, and so are the curriculum planning and outcomes. In order to achieve satisfactory outcomes, the issue as to what the essence of "curriculum" is about should be clarified before any curricular endeavors, such as curriculum planning, implementation, and even evaluations, are attempted (Wen Su, 2012).

The second is human resource aspect. Human resources at school are headmaster, deputy head, teachers, and educational staff. All of human resources which are involved on Full Day School program at SD Negeri Takkalasi have bachelor degree for minimal education qualification. Lack of human resource on this program is lack of teachers who can be involved on talent and interest intensive. The school has involved other teacher and instructor from other school or an organization for talent and interest intensive, but still cannot organize all of students. School still needs more teachers and instructors. Funding for Full Day School program at SD Negeri Takkalasi is limited because it is only obtained from school operational help, so that it is unable to involve many teachers and instructors and school is also limited in purchasing tools and materials for program activity. 
In teachers' new role, teachers should support both the students and their parents. Teachers should act as guides for their students and direct them in their individual processes of development, taking into consideration the challenges of the globalization process (Switala. 2012).

In managing education, financing is the most important factor in education management. Financing component on the school is a production component that determined the learning process activities and other components are accomplished at school (Hidayah, 2017). The third is facility and infrastructure aspects. Facility and infrastructure aspect consist of classroom, headmaster room, teacher room, guest room, library, toilet, mosque, school health unit, green house, rubbish bank, schoolyard or playing location, and canteen. There are twelve classroom at SD Negeri Takkalasi which equipped with bench, table, wall clock, white board, cleanliness tools, picket board, rules board, class blueprint board, students' data board, wall magazine, students' study club board, students' presence clock board, school vision and mission board, teacher ethics code board, class organization structure board, dust bin, and cupboard. Class is equipped with patriot photos and words of wisdom that can take care of students' character. Students' works is displayed on the classroom. School has large enough mosque. There are toilets in clean condition. There are wash basin on each class in front of the class, so that students keep their cleanliness. There is an honest canteen to familiarize students for always being honest in everyday. School yard is completed with beautiful flowers, so that the school fells cool.

Mulyasa (in Hidayah, 2017) explained if management of facility and infrastructure is good, so the school will be clean, neat, and beautiful. The school will be fun school for teachers and students if the school has good management in facility and infrastructure. The school is expected to supply adequate tools or learning facility quantitatively, qualitatively, and relevant to the students' needs, and they can be used optimally for education and learning process by teachers and students.

\section{Process Evaluation of Full Day School Program}

Indicators of program success on process component are lesson plan, learning process, and learning assessment. According to research result, process component of Full Day School program at SD Negeri Takkalasi is in good category.

Based on lesson plan aspect, teachers have prepared lesson plan, learning material, and learning media for Full Day School program at SD Negeri Takkalasi. Learning process is completed with visual aids which prepared by school and also made by teachers.

On religiousness aspect, students shalat in congregation, tilawah, tadarrus, and speech. There are special teachers to guide students in religiousness aspect. Students are guided to do shalat fardhu and shata dhuha together, pronounce Al-Qur'an well, and also memorize Juz 'Amma. There is selection of little da'i.

On arts aspect, there is development of talent and interest on dance and music for students. Students are learnt traditional dance by special teacher who assigned on dance aspect. Students show the dance on the school show. For students who want to develop their talent and interest in music aspect, the students are learnt to play piano and pianika by special teacher too.

On sport aspect, students are provided training of badminton, football, karate, and chess. School provides place for sport. Special for karate, the school has collaboration with people outside the school because there is no teacher who can teach karate. There is also scout activity. 
On knowledge and skill aspect, students are provided mathematics, natural science, and English private course. For mathematics and natural science private course, students are guided for preparation of mathematics and natural science competition for elementary school. On English private course, students are provided speaking, writing, and reading skill because English ability is really important nowadays.

Lesson plan is a written description for this process; where the materials, the method, the time and the place of education as well as methods for evaluating the students are described in detail. Lesson plan is a written description of education process in which it is shown what, when, where and with which method learners should learn and how they should be assessed. Lesson plan is one of the key factors in the educational process (Nesari \& Heidari, 2014)

According to assessment aspect, teachers assess students on cognitive, affective, and psychomotor domain. School also implements evaluation of Full Day School program at SD Negeri Takkalasi. School implements committee meeting with students' parents to report result of Full Day School program at SD Negeri Takkalasi and discusses matters that need to be maintained and fixed on this program.

An effective, goal-oriented, teaching-learning sequence contains clearly understood objectives, productive classroom activities, and a sufficient amount of feedback to make students aware of the strengths and weaknesses of their performances. Feedback and evaluation are inseparably related to both instructional objectives and classroom learning activities and are indispensable elements in the learning process. Classroom assessment and evaluation is like a feedback (Jabbarifar, 2009).

Besides the success of Full Day School program at SD Negeri Takkalasi, there were also some problems like there were students' parents who did not support the the program because of they thought students became tired when back home and students need more money and also there are still students whose teachers were difficult to control because lack of teachers. Number of teachers and number of students are not proportional. The process of Full Day School program at SD Negeri Takkalasi needs support and cooperation from students' parents.

\section{Outcome Evaluation of Full Day School Program}

Indicators of program success for outcome component are students' achievement on affective, cognitive, and psychomotor domain. According to research result, outcome component of Full Day School program at SD Negeri Takkalasi is in good category. Students has good attitude such as, religiousness, discipline, honest, responsibility, politeness, and environmental love. Students say greeting when they meet their teacher and say greeting before they enter to class. After all of students come to class, the students pray before they start the lesson. Students have habit in shalat fardhu and shalat dhuha together. There are 55 students who have memorized Juz 'Amma. Students do not plagiarize on test and finish their task from teacher by themselves without plagiarize other students' tasks. Students come to school on time, finish and assemble their tasks on time, and accomplish cleaning picket. Students respect to their teachers and dressed well based on school's rule. Students always throw rubbish on the dust bin, clean the class before go back home, and shut off the water tap if they do not use it. Cleaning picket task has goal in creating students' attitude like responsibility and environmental love. Students are formed to keep class and school environment cleanliness. Students are protected from bad influence from outside the school because they go home directly after back from school. Students do not have more time to do other activity with others, so students' parents do not be worry about their children. Results of 
religiousness and arts activity, such as tilawah, speech, and dance are showed on Maulid Prophet Muhammad SAW at SD Negeri Takkalasi and watched by headmaster, deputy head, teachers, and students' parents.

Zubaedi (in Hidayati, 2017) said character education is success if students have realized character morals in their daily life, such as politeness, discipline, considerate, gentle, religious, impregnable, simplistic, responsible, empathy, honest, independent, loving science, appreciate others work, lovable, embarrassment, self confidence, rela berkorban, humble, patient, togetherness spirit, loyal, sporty, obedient, takut bersalah, trusting in God, emphatic, diligent, tepat janji, open minded, and persistent.

According to Hasan (in Siregar, 2017), Full Day School as an innovative concept which arises from conventional school system sympathy has excellent side. The first is full day school system allow realization of whole education on cognitive, affective, and psychomotor domain. On conventional education institution, often be disappointed because only capable in forming cognitive domain and really weak in affective and psychomotor domain. Through boarding school system and full day school model, tendency on only cognitive domain could be avoided, thus students' affective and psychomotor domain could be more directed. The second is full day school system allow realization of intensification and effectiveness of education process. Full day school with boarding school model that centralized and 24 hours control system allow realization of intensification of education process because students are easier to be directed and formed based on mission and orientation of institution. Students' activities are easier to be monitored because they have been directed at first. The third is full day school system is effective in application of foreign language.

According to Romli (in Siregar, 2017), the development and innovation concept of full day school learning system is to develop creativity in integration of cognitive, affective, and psychomotor domain. Full day school learning system is packaging of learning method that oriented on education quality during all day long by using fun integrated activity on learning process.

\section{Conclusion}

Evaluation result showed (i) program plan which was consisted of curriculum, facilities, and infrastructure was good, but it had lack of fund and human resources, (ii) implementation of program in religious, arts, sports, scout, and knowledge and skills field was good, but there were students' parents who did not support the program and teachers had difficulty in controlling some students, and (iii) program products were good where students attended sholatul jama'ah and improved their talents, and there were 55 students who had memorized Juz 'Amma. Thus, Full Day School program at SD Negeri Takkalasi can be continued with an additional number of innovative teachers, socialization to students' parents about positive impacts of this program, and additional funds.

\section{Refference}

[1] Arikunto, S. \& Jabar, C.S.A. 2014. Evaluasi Program Pendidikan; Pedoman Teoritis Praktis Bagi Mahasiswa dan Praktisi Pendidikan. Jakarta: Bumi Akasara.

[2] Hidayah, N. 2017. Kesiapan Sekolah dalam Implementasi Program Full Day School (FDS) SD Muhammadiyah di Kota Yogyakarta. Jurnal Pendidikan Sekolah Dasar, $4(1), 38-46$ 
[3] Hidayati, M., Tohiroh, L., \& Istyarini. 2017. Evaluasi Program Pendidikan Akhlak di Full Day School Sekolah Dasar Islam Terpadu. Indonesian Journal of Curriculum and Educational Technology Studies, 5 (1), 10-21.

[4] Jabbarifar, T. 2009. The Importance of Classroom Assessment and Evaluation in Educational System. Proceedings of the 2nd International Conference of Teaching and Learning, 2009, 1-9.

[5] Latief, A. M., \& Hasanah, U. 2017. Evaluasi terhadap Implementasi Pendidikan Karakter dengan Sistem Full Day School pada Madrasah Ibtidaiyah Negeri Al Azhar Asy Syarif Indonesia. Prosiding Kolokium Doktor dan Seminar Hasil Penelitian, 2017, 233-246.

[6] Nesari, A. J. \& Heidari, M. 2014. The Important Role of Lesson Plan on Educational Achievement of Iranian EFL Teachers' Attitudes. International Journal of Foreign Language Teaching \& Research, 3 (5), 25-31.

[7] Rahayu, A., Abidin, Z., \& Susilaningsih. 2018. Evaluasi Program Pembelajaran Full Day School di SDN Bunulrejo 2 Malang. JINOTEP, 4 (2), 82-87.

[8] Siregar, L. Y. S. 2017. Full Day School sebagai Penguatan Pendidikan Karakter (Perspektif Psikologi Pendidikan Islam). Jurnal Pendidikan dan Manajemen Islam, 05 (02), 306-319.

[9] Sudjana, D. 2006. Evaluasi Program Pendidikan Luar Sekolah. Bandung: Remaja Rosdakarya.

[10] Suranto \& Seftiana. 2017. Penerapan Kebijakan Full Day School terhadap Hasil Belajar Siswa. Seminar Nasional Pendidikan, 2017, 181-189.

[11] Świtała, Eugeniusz Stanislaw. 2012. The Professional Role of a Teacher in the Era of Globalization on the Example of Poland. Educational Research eJournal, 1 (1), 61-70.

[12] Tayipnapis, F. Y. 2008. Evaluasi Program dan Instrumen Evaluasi untuk Program Pendidikan dan Penelitian. Jakarta: Rineka Cipta.

[13] Wen Su, Shao. 2012. The Various Concepts of Curriculumand the Factors Involved in Curricula-making. Journal of Language Teaching and Research, 3 (1), 152-158.

[14] Wirawan. 2011. Evaluasi: Teori, Model, Standar, Aplikasi, dan Profesi. Jakarta: Rajawali Pers. 